\title{
Characterizations on the structural and electronic properties of thermal lithiated $\mathrm{Li}_{0.33} \mathrm{MnO}_{2}$
}

\author{
Y.J. Wei ${ }^{\mathrm{a}}$, H. Ehrenberg ${ }^{\mathrm{b}}$, K.B. Kim ${ }^{\mathrm{c}, *}$, C.W. Park ${ }^{\mathrm{d}}$, Z.F. Huang ${ }^{\mathrm{a}}$, C. Baehtz ${ }^{\mathrm{e}}$ \\ a College of Materials Science and Engineering, Jilin University, Changchun 130023, China \\ b Institute for Complex Materials, IFW Dresden, Helmholtzstr. 20, D-01069 Dresden, Germany \\ c Division of Material Science and Engineering, Yonsei University, 134 Shinchon-dong, Seodaemoon-gu, Seoul 120-749, Republic of Korea \\ d Center for Advanced Batteries, Korea Electronics Technology Institute, Republic of Korea \\ e Deutsches Elektronensynchrotron (DESY), Notkestr. 85, D-22607 Hamburg, Germany
}

\section{A R T I C L E I N F O}

\section{Article history:}

Received 27 November 2007

Received in revised form 4 February 2008

Accepted 11 February 2008

Available online 18 April 2008

\section{Keywords:}

Lithium battery

Electrode materials

Crystal structure

Electronic property

\begin{abstract}
A B S T R A C T
A $3 \mathrm{~V}$ cathode material for lithium ion batteries, $\mathrm{Li}_{0.33} \mathrm{MnO}_{2}$, was synthesized by solid-state reaction Two Mn crystallographic positions, $\mathrm{Mn}_{(1)}$ and $\mathrm{Mn}_{(2)}$, were determined by X-ray diffraction analysis. The $\left[\mathrm{Mn}_{(2)} \mathrm{O}_{6}\right]$ octahedron had a lower symmetrical degree than that of $\left[\operatorname{Mn}_{(1)} \mathrm{O}_{6}\right]$, which was attributed to the geometrical effects of the non-symmetrical environment around $\mathrm{Mn}_{(2)}$. $\mathrm{Li}_{0.33} \mathrm{MnO}_{2}$ delivered a reversible discharge capacity $\sim 140 \mathrm{~mA} \mathrm{~h}^{-1}$. In situ synchrotron diffraction clearly showed a reversible phase transition of $\mathrm{Li}_{0.33} \mathrm{MnO}_{2}$ during electrochemical process. The analysis of X-ray absorption near edge spectroscopy observed the conversion of $\mathrm{Mn}^{4+}$ to $\mathrm{Mn}^{3+}$ with $\mathrm{Li}^{+}$intercalation into $\mathrm{Li}_{0.33} \mathrm{MnO}_{2}$, accompanied by the formation of more severely distorted $\left[\mathrm{MnO}_{6}\right]$ octahedron.
\end{abstract}

(c) 2008 Elsevier B.V. All rights reserved.

\section{Introduction}

Lithium ion batteries have been extensively used in portable electronics such as laptop computers, cellular phones, camcorders and cordless tools (4C-market). They are also considered as potential energy storage devices for future hybrid electric vehicles (HEVs) and electric vehicles (EVs). Most of the commercial lithium ion batteries use $\mathrm{LiCoO}_{2}$ as the cathode materials. But, the high cost and toxic properties, along with the safety problems hamper the applications of $\mathrm{LiCoO}_{2}$ in large-scale lithium ion batteries. In recent years, great efforts have been devoted to develop alternative cathode materials to replace $\mathrm{LiCoO}_{2}$. Manganese based oxides are among the most attractive candidates because of their economical and environmental advantages. Scientists have developed many kinds of Mn oxides, which could be sorted by $3 \mathrm{~V}$ (such as $\mathrm{LiMnO}_{2}$ ) [1,2], $4 \mathrm{~V}$ (such as $\mathrm{LiMn}_{2} \mathrm{O}_{4}$ ) [3,4] and $5 \mathrm{~V}$ (such as $\mathrm{LiMn}_{1.5} \mathrm{Ni}_{0.5} \mathrm{O}_{4}$ ) [5,6] cathode materials in the light of discharge potentials.

The thermal lithiated $\mathrm{MnO}_{2}$ (EMD), $\mathrm{Li}_{0.33} \mathrm{MnO}_{2}$, is one of the $3 \mathrm{~V}$ cathode materials, which delivers a reversible discharge capacity of $140-190 \mathrm{~mA} \mathrm{~h} \mathrm{~g}^{-1}$ [7]. The crystal structure of $\mathrm{Li}_{0.33} \mathrm{MnO}_{2}$ has been determined by X-ray diffraction and confirmed in the subse-

\footnotetext{
* Corresponding author. Tel.: +82 2365 7745; fax: +82 23125375 .

E-mail address: kbkim@yonsei.ac.kr (K.B. Kim).
}

quent works by Raman scattering and Fourier transform infrared spectroscopy $[8,9]$. Most of the former works were focused on the synthesis and electrochemical properties of $\mathrm{Li}_{0.33} \mathrm{MnO}_{2}$. However, it is still ambiguous on the structural changes of $\mathrm{Li}_{0.33} \mathrm{MnO}_{2}$ during electrochemical process. Besides this, there is still no report on the electronic properties of as-prepared and electrochemically lithiated $\mathrm{Li}_{0.33} \mathrm{MnO}_{2}$. We have developed recently an in situ battery cell installed on synchrotron diffraction facilities, using which we studied the structural evolution of stoichiometric thermal lithiated $\mathrm{MnO}_{2}$, orthorhombic $\mathrm{LiMnO}_{2}$, during electrochemical process. We reported for the first time that orthorhombic $\mathrm{LiMnO}_{2}$ transforms to a metastable phase during the first cycle before it eventually transforms to spinel $\mathrm{LiMn}_{2} \mathrm{O}_{4}$ [10]. This novel result has not been observed by normal laboratory X-ray diffraction. This indicates that we can obtain high sensitive experimental data by synchrotron radiation, which may lead to finding of new knowledge on material properties. In the present study, high-energy synchrotron techniques, including X-ray diffraction (XRD) and X-ray absorption spectroscopy (XAS) were employed to give clear information on the structural and electronic properties of the as-prepared and electrochemically cycled $\mathrm{Li}_{0.33} \mathrm{MnO}_{2}$.

\section{Experimental}

$\mathrm{Li}_{0.33} \mathrm{MnO}_{2}$ was prepared by the conventional solid-state reaction. For the first step, $\mathrm{MnO}_{2}$ (EMD, Aldrich) powder was pretreated at $250^{\circ} \mathrm{C}$ for $5 \mathrm{~h}$ to remove any adsorbed and chemically bonded water. Then, $\mathrm{MnO}_{2}$ and $\mathrm{LiNO}_{3}(99.5 \%$, Junsei) were 
weighed in a Li:Mn molar ratio of 0.33 , and ball milled to ensure their homogeneous mixing. The resultant mixture was heat treated at $360^{\circ} \mathrm{C}$ for $20 \mathrm{~h}$ at the ambient condition to obtain the final product.

The crystal structure of the material was studied on a STOE STADI/P X-ray powder diffractometer using a monochromic Mo K $\alpha 1$ radiation $(\lambda=0.7093 \AA)$. The $2 \theta$ step for data collection was $0.02^{\circ}$. Rietveld refinement was applied for data analysis using the WinplotR package [11]. The morphology of the material was examined by scanning electron microscopy (SEM, FEI-Company SIRION ${ }^{\mathrm{TM}}$ ). The microstructure of the material was studied by high-resolution transmission electron microscopy (HRTEM) with a JEOL (JEM-2100F) field emission transmission electron microscopy at an acceleration voltage of $200 \mathrm{kV}$.

A three-electrode electrochemical cell with a Li foil and a $\mathrm{Li}$ wire as the counter and reference electrodes was used for the charge-discharge cycling experiment. The working electrode was composed of a mixture of $\mathrm{Li}_{0.33} \mathrm{MnO}_{2}$ (86 wt.\%), carbon black ( $8 \mathrm{wt} . \%$ ), and poly-vinylidenefluoride (PVDF, $6 \mathrm{wt} . \%$ ) dissolved in $N$-methylpyrrolidone (NMP). The electrolyte was a solution of $1 \mathrm{~mol} \mathrm{~L}^{-1} \mathrm{LiClO}_{4}$ dissolved in propylene carbonate (PC). The battery cell was cycled on a WonA Tech WBCS-300 battery cycler. The electrochemical experiment was performed in an argon filled glove box with $\mathrm{H}_{2} \mathrm{O}$ and $\mathrm{O}_{2}$ concentrations below $1 \mathrm{ppm}$.

In situ X-ray diffraction was performed in the transmission mode at the powder diffraction beamline B2 of the Deutsches Elektronensynchrotron (DESY) in Hamburg, Germany. For the in situ XRD measurements, we used a dedicated Swageloktype cell as described elsewhere [12]. A wavelength of $\lambda=0.47189 \AA$ was selected by a double-crystal $\mathrm{Si}(111)$ monochromator. The diffraction data were recorded using the on-site readable image-plate detector OBI [13]. The Mn K-edge X-ray absorption near edge spectroscopy (XANES) was performed in the transmission mode at the beamline 7C at Pohang Light Source (PLS), Korea. Internal reference for the energy calibration was used for a Mn metal foil at each scan. No energy drifts of the monochromator were observed during the experiments. The normalization of the absorption data was performed using the WINXAS'97 package [14]

\section{Results and discussions}

Fig. 1 shows the powder X-ray diffraction pattern of the $\mathrm{Li}_{0.33} \mathrm{MnO}_{2}$ sample. The broad and weak diffraction peaks indicate a small coherent domain size of the material. The mean coherent domain size of the material was about $10 \mathrm{~nm}$ estimated by the Scherer formula [15]. The Rietveld refinement of the diffraction data was carried out based on the monoclinic structure model (space group $\mathrm{C} / 2 \mathrm{~m}$ ) as suggested by Aurbach and coworkers [8]. The refinement parameters are listed in the Table 1. Fig. 2 is a sketch of the crystal structure of $\mathrm{Li}_{0.33} \mathrm{MnO}_{2}$ constructed by the refinement parameters. It is seen from the figure that the crystal structure of $\mathrm{Li}_{0.33} \mathrm{MnO}_{2}$ is composed of an ordered arrangement of [ $\left.1 \times 2\right]$ and $[1 \times 1]$ tunnels. The Li ions were believed to reside in the $[1 \times 2]$ holes since they are much larger than the $[1 \times 1]$ ones. The arrangement of the $\left[\mathrm{MnO}_{6}\right]$ octahedron within the hexagonal close-packed oxygen lattice provided two different sites for Mn ions, named $\mathrm{Mn}_{(1)}$

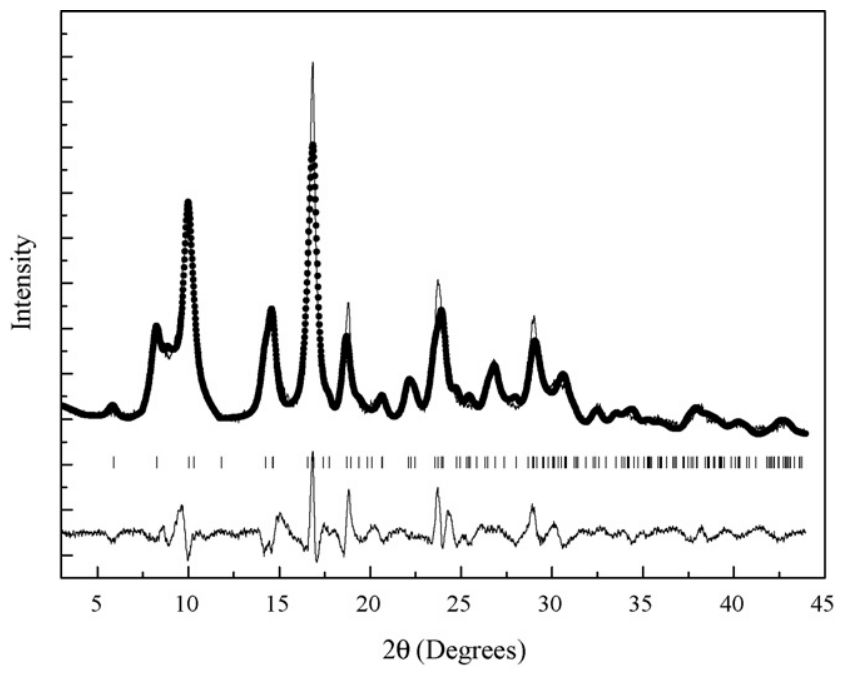

Fig. 1. Rietveld refinement result of the X-ray diffraction data of $\mathrm{Li}_{0.33} \mathrm{MnO}_{2}$.
Table 1

Rietveld refinement structural parameters of the $\mathrm{Li}_{0.33} \mathrm{MnO}_{2}$ material

\begin{tabular}{lllll}
\hline Phase & Atom & \multicolumn{2}{l}{ Atom position } & \\
\cline { 3 - 5 } & & $x$ & $y$ & $z$ \\
\hline & $\mathrm{Mn}_{(1)}$ & 0 & 0 & 0 \\
$\mathrm{Mn}_{0.33} \mathrm{MnO}_{2}$ & $\mathrm{O}_{(1)}$ & 0.342 & 0 & 0.477 \\
& $\mathrm{O}_{(2)}$ & 0.058 & 0 & 0.339 \\
& $\mathrm{O}_{(3)}$ & 0.412 & 0 & 0.183 \\
& 0.239 & 0 & 0.770 \\
\hline
\end{tabular}

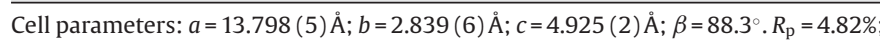
$R_{\mathrm{wp}}=6.29 \% ; R_{\exp }=1.38 \%$.

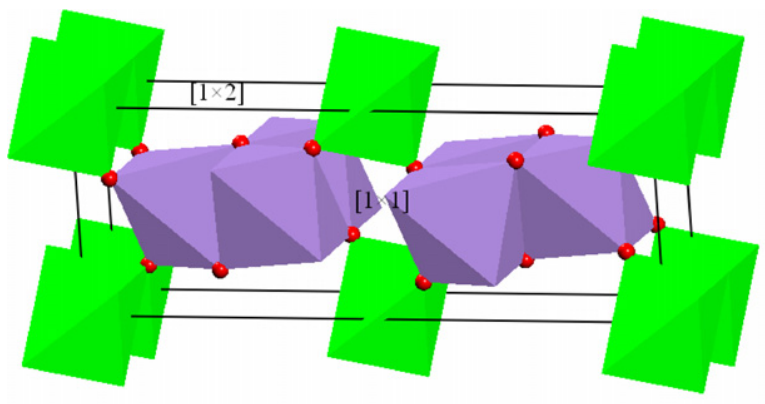

1

Fig. 2. Sketch of the crystal structure of $\mathrm{Li}_{0.33} \mathrm{MnO}_{2}$. The red balls represent the "O" atoms. The regions in green and purple represent the $\left[\mathrm{Mn}_{(1)} \mathrm{O}_{6}\right]$ and $\left[\mathrm{Mn}_{(2)} \mathrm{O}_{6}\right]$ octahedron, respectively. The $[1 \times 2]$ and $[1 \times 1]$ tunnels are marked in the figure.

Table 2

$\mathrm{Mn}-\mathrm{O}$ bond lengths of the $\left[\mathrm{MnO}_{6}\right]$ octahedron in $\mathrm{Li}_{0.33} \mathrm{MnO}_{2}$

\begin{tabular}{llll}
\hline & Bond & Number & Bond length $(\AA)$ \\
\hline$\left[\mathrm{Mn}_{(1)} \mathrm{O}_{6}\right]$ & $\mathrm{Mn}_{(1)}-\mathrm{O}_{(1)}$ & 2 & 1.88 \\
& $\mathrm{Mn}_{(1)}-\mathrm{O}_{(2)}$ & 4 & 2.06 \\
& $\mathrm{Mn}_{(2)}-\mathrm{O}_{(1)}$ & 2 & 2.19 \\
{$\left[\mathrm{Mn}_{(2)} \mathrm{O}_{6}\right]$} & $\mathrm{Mn}_{(2)}-\mathrm{O}_{(2)}$ & 1 & 1.72 \\
& $\mathrm{Mn}_{(2)}-\mathrm{O}_{(3)}$ & 2 & 2.20 \\
& $\mathrm{Mn}_{(2)}-\mathrm{O}_{(3)}$ & 1 & 2.00 \\
\hline
\end{tabular}

and $\mathrm{Mn}_{(2)}$, respectively. Table 2 lists the $\mathrm{Mn}-\mathrm{O}$ lengths of the $\left[\mathrm{MnO}_{6}\right]$ octahedron in $\mathrm{Li}_{0.33} \mathrm{MnO}_{2}$. It indicates that the $\left[\mathrm{Mn}_{(2)} \mathrm{O}_{6}\right]$ octahedron had a lower symmetrical degree than that of $\left[\mathrm{Mn}_{(1)} \mathrm{O}_{6}\right]$. The low symmetrical degree of the $\left[\mathrm{Mn}_{(2)} \mathrm{O}_{6}\right]$ octahedron was attributed to the geometrical effects of the non-symmetrical atomic environment around the $\mathrm{Mn}_{(2)}$ site.

Fig. 3 shows the SEM image of the $\mathrm{Li}_{0.33} \mathrm{MnO}_{2}$ sample. SEM shows that the material was composed of irregular shaped and

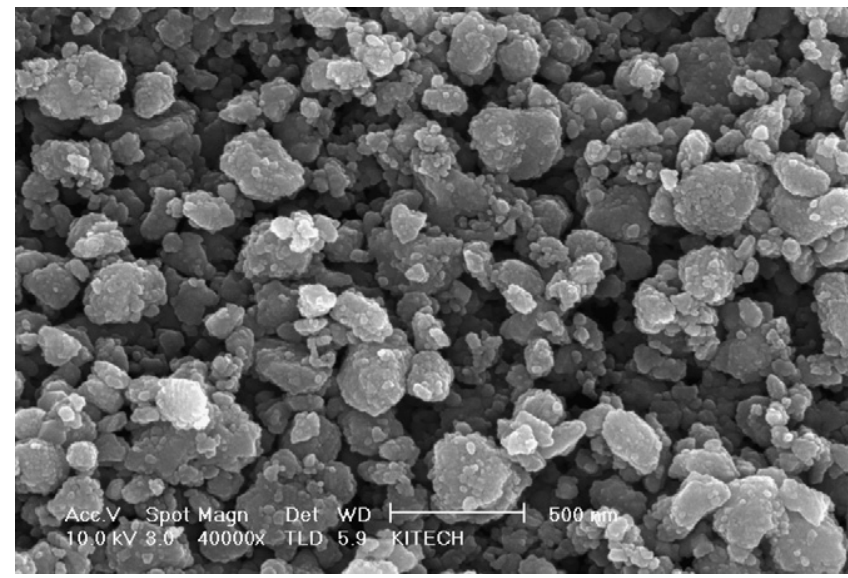

Fig. 3. SEM image of the $\mathrm{Li}_{0.33} \mathrm{MnO}_{2}$ material. 


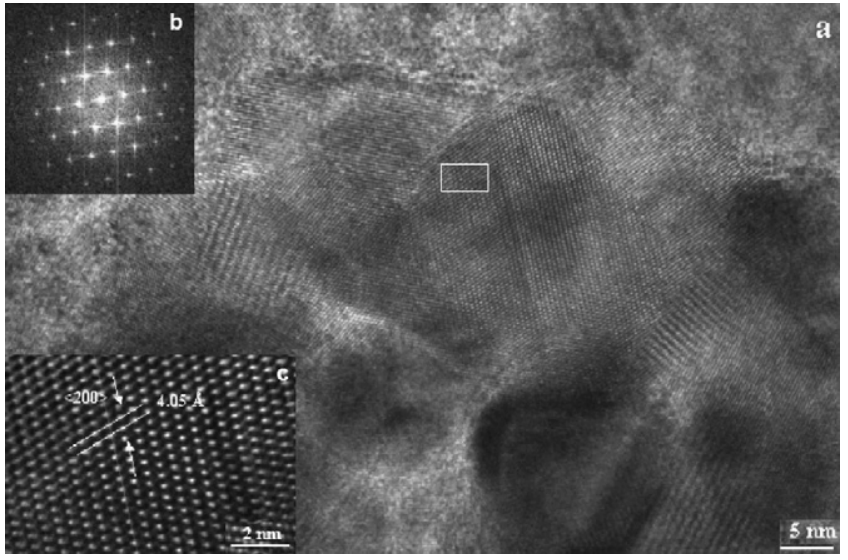

Fig. 4. (a) HRTEM image of the $\mathrm{Li}_{0.33} \mathrm{MnO}_{2}$ material. (b) Selected-area electron diffraction pattern (SAED) of an individual domain particle. (c) HRTEM image of an individual domain particle.

sized particles. The geometric particle size ranged randomly from several tens to hundreds nanometers. The HRTEM image presented in Fig. 4(a) clearly shows that the material was polycrystalline. The mean coherent domain size determined from HRTEM was about $10 \mathrm{~nm}$, which is consistent with that estimated by Scherer formula. The selected-area electron diffraction pattern (SAED) shown in Fig. 4(b) indicates that the domain particles were well crystallized. The lattice fringe of $4.05 \AA$ in the HRTEM image (Fig. 4(c)) corresponds to the (200) plane, which is consistent with the X-ray diffraction result.

Fig. 5 displays the typical discharge-charge potential profiles of $\mathrm{Li}_{0.33} \mathrm{MnO}_{2}$. The material showed an open circuit potential at $\sim 3.4 \mathrm{~V}$. When the material was discharged to $2.0 \mathrm{~V}$, the capacity was determined as $168 \mathrm{~mA} \mathrm{~h}^{-1}$, corresponding to $0.59 \mathrm{~mol}$ of Li intercalation into $\mathrm{Li}_{0.33+x} \mathrm{MnO}_{2}$ according to the reaction:

$\mathrm{Li}_{0.33} \mathrm{MnO}_{2}+0.59 \mathrm{Li}^{+}+0.59 \mathrm{e}^{-}=\mathrm{Li}_{0.92} \mathrm{MnO}_{2}$

Therefore the composition of the cathode material after the first discharge was $\mathrm{Li}_{0.92} \mathrm{MnO}_{2}$, which was close to the ideal composition $\left(\mathrm{LiMnO}_{2}\right)$ of fully lithiated $\mathrm{Li}_{0.33} \mathrm{MnO}_{2}$. The potential profiles were characterized by a single discharge plateau centered at $\sim 2.9 \mathrm{~V}$ and a charge plateau centered at $\sim 3.1 \mathrm{~V}$. The shape of the potential profiles did not change much with cycling, highlighting the good reversibility of the material. The discharge capacities versus cycle numbers of the material were plotted in Fig. 6. It is shown that the

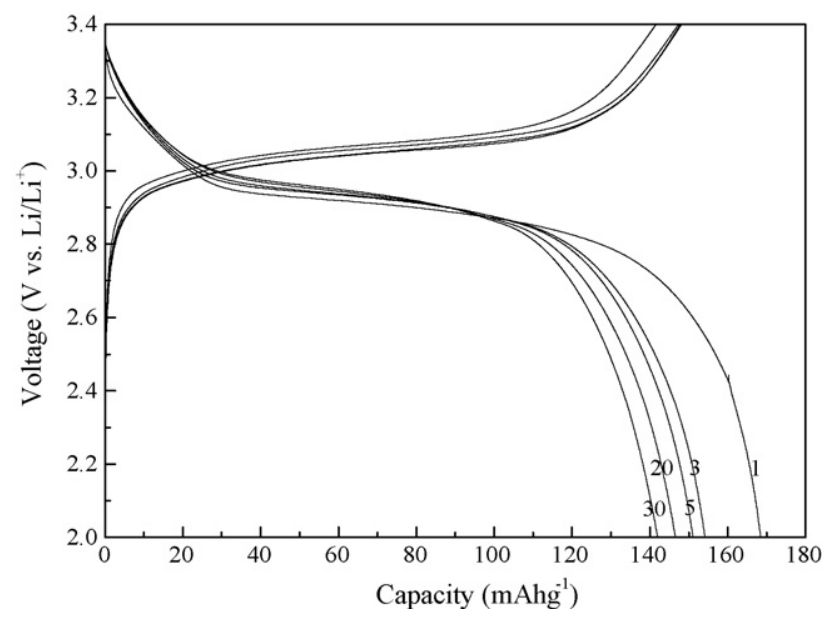

Fig. 5. Typical discharge-charge potential profiles of the $\mathrm{Li}_{0.33} \mathrm{MnO}_{2}$ material.

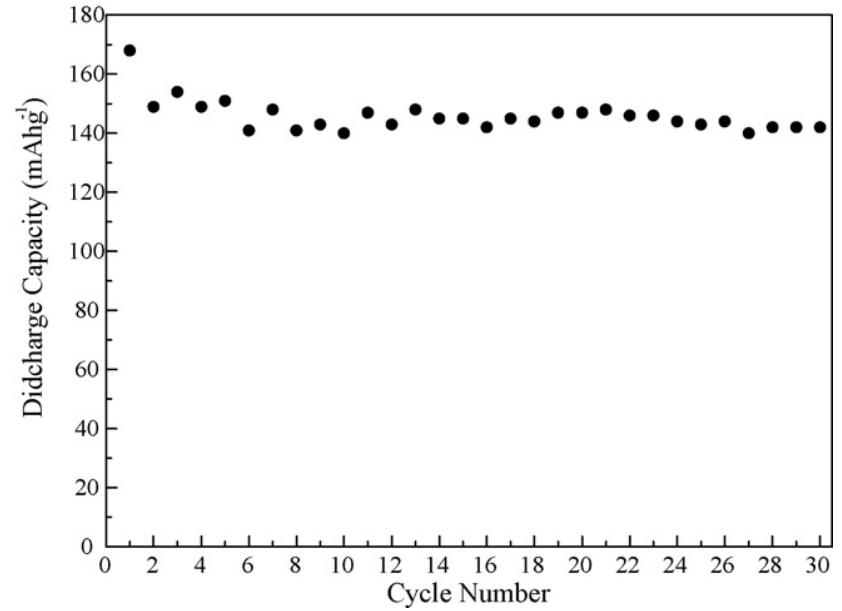

Fig. 6. Discharge capacities vs. cycle numbers of the $\mathrm{Li}_{0.33} \mathrm{MnO}_{2}$ material.

material delivered a reversible discharge capacity of $140 \mathrm{~mA} \mathrm{~h} \mathrm{~g}^{-1}$ over 30 cycles.

Even though the crystal structure of $\mathrm{Li}_{0.33} \mathrm{MnO}_{2}$ has been well established, it is still ambiguous on the structural changes of this material during electrochemical process. Ohzuku et al. [16] assumed that the material's structure was practically unchanged during Li intercalation. However, the voltage plateau near $2.9 \mathrm{~V}$ on the discharge potential profile clearly indicates a phase transition and the coexistence of two phases. Aurbach and coworkers [17] observed different XRD patterns of the fully electrochemically lithiated $\mathrm{Li}_{0.33} \mathrm{MnO}_{2}$ with respect to that of the as-prepared $\mathrm{Li}_{0.33} \mathrm{MnO}_{2}$. They attributed this to a phase transition occurring in the cathode material as $\mathrm{Li}$ intercalation. In order to examine the structural changes more clearly, we collected the in situ XRD patterns of $\mathrm{Li}_{0.33} \mathrm{MnO}_{2}$ during the first discharge-charge cycle, which are shown in Fig. 7. At the first sight, these diffraction patterns are poorly recognized, reflecting the long-range disordering or poor crystallinity of the material. During the discharge process (Li intercalation), all of the diffraction peaks shifted towards lower $2 \theta$ angles. This corresponds to an expansion in the material lattice with $\mathrm{Li}$ intercalation. Besides this, the diffraction peaks at $2 \theta \approx 15.8^{\circ}$ progressively weakened and eventually disappeared at the end of discharge. At the same time, a new diffraction appeared at $2 \theta \approx 18.7^{\circ}$, and its intensity increased gradually with Li interca-

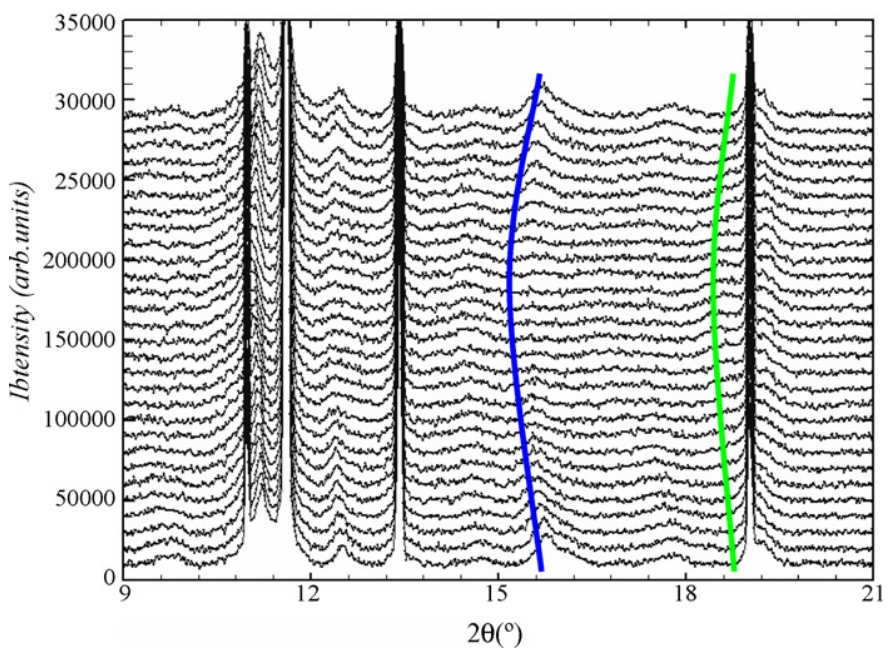

Fig. 7. In situ diffraction patterns of $\mathrm{Li}_{0.33} \mathrm{MnO}_{2}$ during the first discharge-charge cycle. 


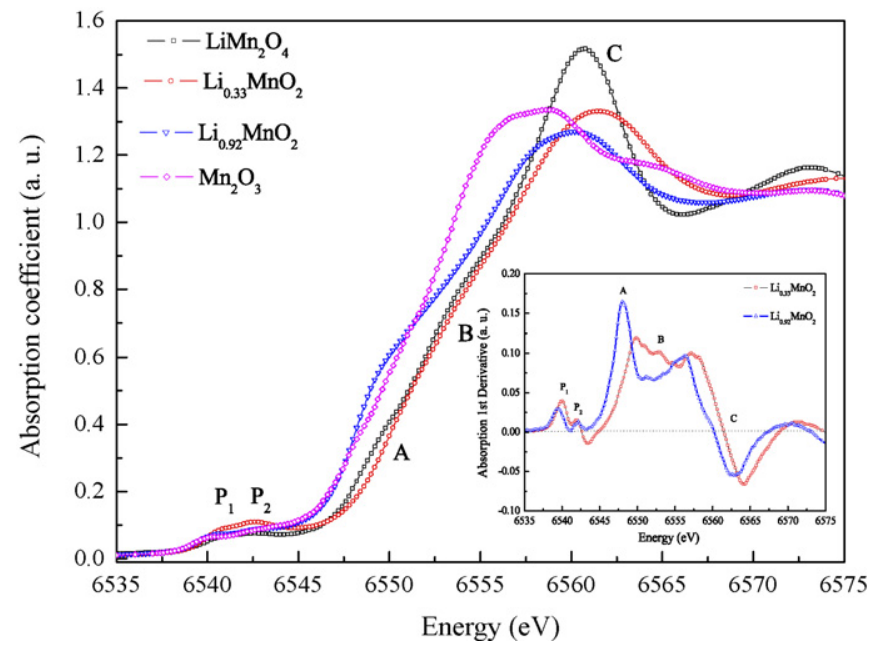

Fig. 8. Mn K-edge XANES of $\mathrm{Li}_{0.33} \mathrm{MnO}_{2}$ and $\mathrm{Li}_{0.92} \mathrm{MnO}_{2}$, along with those of $\mathrm{LiMn}_{2} \mathrm{O}_{4}$ and $\mathrm{Mn}_{2} \mathrm{O}_{3}$. The insert pattern is the first derivatives of the XANES profiles of $\mathrm{Li}_{0.33} \mathrm{MnO}_{2}$ and $\mathrm{Li}_{0.96} \mathrm{MnO}_{2}$.

lation. These observations clearly indicate a structural transition occurring in the cathode material, which transformed to a new phase at the end of discharge process. However, it was still an intrinsic challenge to determine the crystal structure of this newly formed phase based on the current poor diffraction patterns. The evolution of the diffraction patterns was reversed in the subsequent charge process. The diffraction pattern after the first charge fits well with that of the as-prepared $\mathrm{Li}_{0.33} \mathrm{MnO}_{2}$ again, indicating the reversibility of this structural transition during electrochemical process.

The Mn K-edge XANES is very sensitive to the local symmetry of $\mathrm{Mn}$ as well as to the associated charge of Mn itself. Fig. 8 displays the Mn K-edge XANES of the as-prepared $\mathrm{Li}_{0.33} \mathrm{MnO}_{2}$ and the electrochemically lithiated $\mathrm{Li}_{0.33} \mathrm{MnO}_{2}\left(\mathrm{Li}_{0.92} \mathrm{MnO}_{2}\right)$, together with those of $\mathrm{LiMn}_{2} \mathrm{O}_{4}$ and $\mathrm{Mn}_{2} \mathrm{O}_{3}$ as the reference materials. The edge jump position for the as-prepared $\mathrm{Li}_{0.33} \mathrm{MnO}_{2}$ was higher than that of $\mathrm{LiMn}_{2} \mathrm{O}_{4}$. This is consistence with the fact that the Mn oxidation state of $\mathrm{Li}_{0.33} \mathrm{MnO}_{2}\left(\mathrm{Mn}^{3.67+}\right)$ is higher than that of $\mathrm{LiMn}_{2} \mathrm{O}_{4}$ $\left(\mathrm{Mn}^{3.5+}\right)$. The XANES shifted towards lower energies with Li intercalation, which corresponds to the decrease of the Mn oxidation state. It is noticeable that the edge jump position of $\mathrm{Li}_{0.92} \mathrm{MnO}_{2}$ was slightly higher than that of $\mathrm{Mn}_{2} \mathrm{O}_{3}$. This is reasonable because the Mn oxidation state of $\mathrm{Li}_{0.92} \mathrm{MnO}_{2}\left(\mathrm{Mn}^{3.08+}\right)$ is a little bit larger than +3 .

The double pre-edge peaks $P_{1}$ and $P_{2}$ on the Mn K-edge XANES are well known to be due to a formally forbidden $1 \mathrm{~s} \rightarrow 3 \mathrm{~d}$ structural transition, which is dipole allowed if the full local $O_{h}$ symmetry is decreased. The split in the pre-edge peaks originates from the separation of the degenerated $3 \mathrm{~d}$ levels under the effect of an octahedral crystal field. $P_{1}$ and $P_{2}$ have been assigned to the $1 \mathrm{~s} \rightarrow 3 \mathrm{~d}_{\mathrm{eg}}$ and $1 \mathrm{~s} \rightarrow 3 \mathrm{~d}_{\mathrm{t} 2 \mathrm{~g}}$ transitions, respectively [18]. From the first derivations of XANES, the energy difference between $P_{1}$ and $P_{2}, \Delta E\left(P_{2}-P_{1}\right)$, was determined as $2.0 \mathrm{eV}$ and $2.8 \mathrm{eV}$ for $\mathrm{Li}_{0.33} \mathrm{MnO}_{2}$ and $\mathrm{Li}_{0.92} \mathrm{MnO}_{2}$, respectively. The large $\Delta E\left(P_{2}-P_{1}\right)$ value of $\mathrm{Li}_{0.92} \mathrm{MnO}_{2}$ reflects a broad splitting between the Mn $\mathrm{d}_{\mathrm{t} 2 \mathrm{~g}}$ and $\mathrm{d}_{\mathrm{eg}}$ levels. No significant change was observed in the peak intensity of $P_{2}$ with Li intercalation in contrast to the considerable decrease of $P_{1}$. This can be explained by the Mn 3d electronic configurations. Firstly, both $\mathrm{Mn}^{4+}$ and $\mathrm{Mn}^{3+}$ ions have half filled $\mathrm{d}_{\mathrm{t} 2 \mathrm{~g}}$ orbitals. A change in $\mathrm{Mn}^{4+}$ and $\mathrm{Mn}^{3+}$ concentrations in $\mathrm{Li}_{x} \mathrm{MnO}_{2}$ does not cause a significant change in the probability of $1 \mathrm{~s} \rightarrow 3 \mathrm{~d}_{\mathrm{t} 2 \mathrm{~g}}$ transitions. However, the higher $\mathrm{Mn}^{3+}$ concentration in lithiated $\mathrm{Li}_{0.33} \mathrm{MnO}_{2}$ leads to filling more electrons in the $d_{\text {eg }}$ orbital. This would decrease the probability of $1 \mathrm{~s} \rightarrow 3 \mathrm{~d}_{\mathrm{eg}}$ transitions, therefore, result in a weak $P_{1}$ signal.
The three features of "A", "B" and " $C$ " on the Mn K-edge XANES are assigned to the dipole allowed $1 \mathrm{~s} \rightarrow 4 \mathrm{p}$ transitions, among which "A" corresponds to the $1 \mathrm{~s} \rightarrow 4 \mathrm{p}_{z}$ transition of the Mn ions with a shakedown process followed by a ligand to metal charge transfer (LMCT) [19]. The intensity and position of "A" provides a measure for the local structure around the Mn ions. A stronger signal of " $\mathrm{A}$ " in $\mathrm{Li}_{0.92} \mathrm{MnO}_{2}$ could be attributed to the more severely distorted $\left[\mathrm{MnO}_{6}\right]$ octahedron, because the distortion facilities the LMCT and hence the shakedown process. In addition, it was reported that the distortion of the $\left[\mathrm{MnO}_{6}\right]$ octahedron also facilitates the feature " $A$ " shifting towards lower energies [20]. In this study, the energy positions of " $A$ " were determined at $6550 \mathrm{eV}$ and $6548 \mathrm{eV}$ for the as-prepared $\mathrm{Li}_{0.33} \mathrm{MnO}_{2}$ and lithiated $\mathrm{Li}_{0.92} \mathrm{MnO}_{2}$, respectively, which is concordant to the increase of the $\left[\mathrm{MnO}_{6}\right]$ distortion with Li intercalation.

\section{Conclusions}

In this work we prepared a $\mathrm{Li}_{0.33} \mathrm{MnO}_{2}$ powder using conventional solid-state reaction. The material had a monoclinic structure with an ordered arrangement of [ $1 \times 2]$ and $[1 \times 1]$ tunnels, and two different $\mathrm{Mn}$ sites. The $\left[\mathrm{Mn}_{(2)} \mathrm{O}_{6}\right]$ octahedron had a lower symmetrical degree than that of $\left[\mathrm{Mn}_{(1)} \mathrm{O}_{6}\right]$, which could be attributed to the geometrical effects of the non-symmetrical environment around $\mathrm{Mn}_{(2)}$. In situ X-ray diffraction clearly showed a reversible phase transition for $\mathrm{Li}_{0.33} \mathrm{MnO}_{2}$ during electrochemical process. However, the crystal structural of this newly formed phase has not been resolved because of the poor diffraction patterns. Li intercalation into $\mathrm{Li}_{0.33} \mathrm{MnO}_{2}$ led to the conversion of $\mathrm{Mn}^{4+}$ to $\mathrm{Mn}^{3+}$, which was accompanied by the formation of more severely distorted $\left[\mathrm{MnO}_{6}\right]$ octahedron.

\section{Acknowledgements}

This work was supported by MIC and MOCIE, Korea. This work was also benefited from the Deutsche Forschungsgemeinschaft (DFG) within the project 595 "Electrical fatigue in functional materials". The design of the in situ setups for synchrotron diffraction experiments was supported by the Helmholtz Association of National Research Centres (HGF) in the frame of the virtual institute VH-VI-102.

\section{References}

[1] J.N. Reimers, Eric W. Fuller, Erik Rossen, J.R. Dahn, J. Electrochem. Soc. 140(1993) 3396.

[2] A.R. Armstrong, P.G. Bruce, Nature 381 (1996) 499.

[3] N. Hayashi, H. Ikuta, M. Wakihara, J. Electrochem. Soc. 146 (1999) 1351.

[4] M.R. Palacín, Y. Chabre, L. Dupont, M. Hervieu, P. Strobel, G. Rousse, C. Masquelier, M. Anne, G.G. Amatucci, J.M. Tarascon, J. Electrochem. Soc. 147 (2000) 845.

[5] S. Mandal, R.M. Rojas, J.M. Amarilla, P. Calle, N.V. Kosova, V.F. Anufrienko, J.M. Rojo, Chem. Mater. 14 (2002) 1598.

[6] F.G.B. Ooms, E.M. Kelder, J. Schoonman, M. Wagemaker, F.M. Mulder, Solid State Ionics 152-153 (2002) 143.

[7] M. Yoshio, H. Nakamura, Y.Y. Xia, Electrochim. Acta 45 (1999) 273.

[8] E. Levi, E. Zinigrad, H. Teller, M.D. Levi, D. Aurbach, J. Electrochem. Soc. 145 (1998) 3440

[9] B. Banov, A. Momchilov, M. Massot, C.M. Julien, Mater. Sci. Eng. B 100 (2003) 87.

[10] Y.J. Wei, H. Ehrenberg, N.N. Bramnik, K. Nikolowski, C. Baehtz, H. Fuess, Solid State Ionics 178 (2007) 253.

[11] T. Roisnel, J. Rodriguez-Carvajal, Mater. Sci. Forum 118 (2001) 378

[12] K. Nikolowski, C. Baehtz, N.N. Bramnik, H. Ehrenberg, J. Appl. Crystal. 38 (2005) 851.

[13] M. Knapp, V. Joco, C. Baehtz, H.H. Brecht, A. Berghaeuser, H. Ehrenberg, H. von Seggern, H. Fuess, Nucl. Instrum. Methods A521 (2004) 565.

[14] T. Ressler, J. Phys. IV 7 (1997) 269.

[15] Y.J. Wei, Z.F. Huang, C.Z. Wang, W. Liu, G. Chen, Eur. Phys. J.-Appl. Phys. 23 (2003) 111.

[16] T. Ohzuku, M. Kitagawa, T. Hirai, J. Electrochem. Soc. 137 (1990) 40. 
[17] E. Levi, E. Zinigrad, H. Teller, M.D. Levi, D. Aurbach, E. Mengeritsky, E. Elster, P. Dan, E. Granot, H. Yamin, J. Electrochem. Soc. 144 (1997) 4133.

[18] N. Treuil, C. Labrugère, M. Menetrier, J. Portier, G. Campet, A. Deshayes, J.C. Frison, S.J. Hwang, S.W. Song, J.H. Choy, J. Phys. Chem. B 103 (1999) 2100.
[19] S.J. Hwang, D.H. Park, J.H. Choy, G. Campet, J. Phys. Chem. B 108 (2004) 12713.

[20] C.R. Horne, U. Bergmann, M.M. Grush, R.C.C. Perera, D.L. Ederer, T.A. Callcott, E.J. Cairns, S.P. Cramer, J. Phys. Chem. B 104 (2000) 9587. 